\title{
The Effect of Parental Support on Academic Performance among Students at Asia-Pacific International University
}

\author{
Linda Wong Siew Yieng ${ }^{1}$, Josephine Esther Katenga ${ }^{2}$, Jimmy Kijai ${ }^{3}$ \\ ${ }^{1,2}$ Faculty of Education Asia-Pacific International University, Thailand \\ ${ }^{3}$ School of Education, Andrews University, USA \\ wong_linda0912@yahoo.com
}

\begin{abstract}
Literature indicates that parental support influences better academic achievement and helps college level students undergo personal and social development. Parents support includes helping the child plan for higher education, choosing types of college to attend, financing a college education, and providing emotional and social support. This study aimed at investigating whether parents support of their college children results in better academic outcomes. Using stratified sampling, 60 undergraduate students aged between 17 years to 25 years old from five Asia-Pacific International University (AIU) dormitories were selected to participate in this study. A survey instrument for data collection consisted of a demographic questionnaire and a Likert-scale questionnaire. The data were analyzed using Statistical Package for Social Sciences (SPSS) for Windows, Version 21. An independent samples t-test was used to determine the differences between Thai and International students on parental support. Spearman rho correlation coefficients between parental involvement variables and cumulative grade point averages (CGPA) were reported. Results: Findings of this study showed that although there is positive influence on the family relationship between the parents and students at the college level, it does not adequately explain academic performance among students. In addition, the level of support received by the Thai students was higher than that received by international students. There are a variety of factors that influence academic success. Therefore, parental support alone cannot by itself explain students' academic achievement. As for the level of support received by Thai students, the proximity of Thai students to their parents may be a factor for the level of support they receive. The findings do show that administrators should look into how parents support their college students and establish strategies for encouraging adequate emotional and social parental support even for international college students. Future research should use mixed methods research design to focus on the impact of little or no parental support on students' well-being and academic outcomes.
\end{abstract}

Keywords: Cumulative Grade Point Average (CGPA), Helicopter parents, Parents/guardian Parental Involvement, Parental support. 


\section{INTRODUCTION}

Many studies show that parental support does not end even when the child goes to college (Edelman, 2013; Ratelle, Larose, Guay \& Sene'cal; 2005; Savage, 2009; Winegard, 2010). Cheng, Ickes, and Verhofstadt, 2012 suggest that parental support influences better academic achievement, and helps students undergo personal and social development. Besides, parental involvement plays a role in students' well-being and translates into the students' ability to develop critical thinking useful for academic achievement at the college level (Román, Cuestas \& Fenollar, 2008).

Parental involvement at the college level begins before the children graduate from high school. In most cases, parents talk about their aspirations for their children (Ceja, 2004; Irwin \& Elley, 2013). In some cultures, parents help their children to consider higher education (Smith \& Fleming, 2006). Sometimes parents engage in college planning (Borders et al., 2011) and prepare their children for high school and college transition (Edelman, 2013). Some parents assist their children to choose college to attend (Ma, 2009). This is specifically true for Christian parents (Shaw, 2005) who want their children to embrace Christian morals. Unfortunately, higher education is costly, and students find it difficult to cope and have to rely on their parents for financial support (Jack, 2003; Savage, 2009) to fund college tuition and fees (Johnstone, 2005).

The transition from high school to college leads to a whole new experience, which can be exciting as students encounter familiar and unfamiliar regulations and situations, and at the same time challenging as students begin to consider and understand college high academic expectations and the different social environments (Astin, 1968, Bozick, 2007). They become surprised by the freedom and pressures of college life. Academic demands and social life become intertwined and difficult (Cheng, Icke, \& Verhofstadt, 2012). Making new friends becomes tricky when it requires breaking into already existing groups and cliques (Littleton, 2002). However, students have to learn to self-regulate to participate in their own learning and take responsibility of their academic achievement (Astin, 1968, Chickering, 1993).

Parents' relationship with their college students become significant during these struggles, especially if there is a connection between child and parents. Edelman (2013) suggests that in recent years, parents have been involved in their children's education, and therefore, they continue supporting their college children. During this transition and throughout the four years of college, parents find themselves offering emotional support (Sax \& Weintraub, 2014). Often parents have engaged to socialize their children, providing them an avenue for discussing their 
positive and negative college experiences (Weidman, 2014) and seek advice (Edelman, 2013). These relationships also encourage students to continue in courses they have difficulties with (Ratelle, Larose, Guay \& Sene'cal, 2005) and ultimately parents' support helps the children to persist in college (Perna \& Thomas, 2008; Tinto, 1993).

Coleman (1988) suggests that parents provide social capital to their children when they have a relationship with the school and mutually share goals for the students' wellbeing which helps the students to adjust to college life.

Some studies, however, show that parental involvement has negative effect and does not affect college achievement (Kiyama, \& Harper, 2015; Kwon, Yoo \& Bingham, 2016; LeMoyne \& Buchanan, 2011; Schiffrin et al., 2014; Spain, 2008). Findings show that overly controlling helicopter parents negatively affect students' wellbeing. A study done at a Korean University discovered that students' locus of control was affected and did not develop resilience or stability because of their helicopter parents (Kwon, Yoo, \& Bingham, 2016; Suizzo, \& Soon, 2006).

It is safe to conclude that research results show lack agreement about the effect of parental support on academic outcome. The benefits depend on the student and the type of support he receives. Nevertheless, Savage (2009) summarizes parents role s as “Parents are children's first support system, emotionally and financially, and that does not change just because a student starts college" (Savage, 2009, p. 2) even if the parents' involvement affects the students negatively.

\section{Problem Statement}

Most of the studies on parental involvement at the college level point to financial support, emotional support, and social support. These types of support provide stability, which in turn, help the students to adjust to college life and to concentrate on their academics. On the other hand, parental involvement can be detrimental to some students and can result in poor educational outcomes (Kwon, Yoo \& Bingham, 2016; LeMoyne \& Buchanan, 2011). The discussion above seems to confirm the argument by Cheng, Icke, \& Verhofstadt, (2012) that findings regarding parents' role in university students' academic lives and academic achievement are inconsistent. Therefore, the present study explored the effect of parental involvement on college academic achievement at Asia Pacific International University (AIU).

\section{Purpose of the study}

The purpose of this study was to determine whether a correlation exists between parent support and student academic performance of Thai and International students at Asia-Pacific 
International University. The study has three objectives: a) to discover the nature of support parents provide; b) to determine the effect of parents' support on children's academics and c) to find out the differences between Thai students and international students

\section{LITERATURE REVIEW}

\section{Parental Involvement at the College Level}

At the college level, parental support becomes more indirect because the student begins to take greater responsibility for his social life. Chickering and Reisser (1993) theorized that a key step for college students is learning to function independently without constant reassurance or approval, and that step begins with separation from family. The students begin to make their own decisions (Tugend, 2014).

Even though there is a need for autonomy, many college students today continue to have a relationship with their parents (Harper, Sax, \& Wolf, 2012). Parents who have good relationships with their children spend time socializing with them. Academic socialization is the preferred mode of involvement (Ratelle, Larose, Guay \& Sene'cal, 2005). This involves interaction with the student about their college experiences-routines, interest and academic performance and challenges regarding their social life. Also, parents encourage their children to persist in college. A study conducted by Ratelle, Larose, Guay, and Sene'cal (2005) shows that parents spent time encouraging their college children to persist in a Science curriculum.

\section{Academic Performance}

Academic performance is defined as how a student does well in school. The student's achievement is measured by a students' performance using a variety of assessments which are cumulatively reflected in the Grade Point Average (GPA). There are a variety of factors that affect student academic performance. Some of these factors include a) classroom environment factors, such as teachers' effectiveness in the classroom (Wayne, Garet, Wellington, \& Chiang, 2008), and teacher and student relationship; b) students' factors such as, student academic interaction and study habits (Rabia, Mubarak, Tallat, \& Nasir, 2017; Arshad, Shahzadi, \& Mahmood, 2016; Shahzadi \& Ahmad, 2011); c) peer relationship (Brunello \& De Paola, 2010; Wentzel, \& Caldwell, 2006, Scoppa and De Paola 2010); and d) home environment which includes parental support.

\section{Parental Support and Academic Performance}

Several studies that have investigated the influence of family support on college students' academic performance (Edelman 2013; Ratelle, Larose, Guay \& Sene'cal; 2005; Savage, 2009; 
Spain, 2008; Winegard, 2010). However, very few parents provide academic support. What literature shows is that parental academic support at the college level takes on different forms but does not include direct academic support. Parents feel less capable of assisting academically because the college curriculum is more advanced. In fact, parents are unable to provide much counsel in social issues as the college student no longer seek permission for their actions (Tugend, 2014; Jeynes, 2007).

The attachment theory proposed by Kek, Darmawan, and Chen (2007) shows the indirect ways parental involvement affects academic performance. Kek, Darmawan, and Chen (2007) argue that growing up in a secure, supportive family environment tends to foster high levels of selfefficacy which includes academic self-efficacy and therefore facilitates a range of usefully adaptive behaviors. The relationship parents have with their children promotes lifelong lessons in critical thinking and helps to develop the children's self-efficacy. When parents demonstrate close involvement in their children's education and provide academic and emotional encouragement, the children value their support and leads to student wellbeing (Arnett, 2000; Harper, Sax \& Wolf, 2012; Román, Cuestas \& Fenollar; 2008).

\section{Parental Social Support}

Parental social support satisfies children's fundamental needs for acceptance, belonging, and love. These needs cannot be satisfied with economic security alone (Wintre et al., 2011). Parental social support is defined as a perception of how much the family cares about, values, and encourages the students' efforts to succeed in college (Leonard. 2013). Parents can promote the development of dependability, perseverance, and a work ethic. Parents achieve this by cooperating with others who have similar goals for the student Coleman's (1988).

\section{Parental Emotional Support}

Adjusting to college life is a major transition that college students face in their first year. For many, the transition includes moving out of the family home for the first time, making new friends, and facing increased academic demands. However, a higher rate of parent and student interaction can sometimes be positive, resulting in the child's better adjustment to university life (Turner, Chandler \& Heffer, 2009). Family support and intervention helps the student to cope and have a positive adjustment. Wintre et al. (2011) found that academia-related stress levels are high in university students, and students frequently seek support from their family, but not from friends (Flowers III, 2015). In addition, Flowers reports that most university students contact their parents when they are in their early academic years. In another study, 
William (2005) found that students' level of family support were related to their confidence in their parents' capacity to deal with challenging experiences.

Parental Financial Support

Parental financial support is also important as a distinct aspect of parental involvement. Parental financial support refers to the material support that the child receives from his or her family in their education. The rising cost of education cause students who do no hold jobs to seek sponsorship for their education (Arnett, 2000; Leonard, 2013; Schoeni \& Ross, 2004). In assisting students, parents pay for school supplies, food, accommodation, transportation, or fees for sports. Students in the developed world are offered scholarships. However, private universities that depend on students' tuition to survive, often do not have scholarships for students (Arnett, 2000). Fan \& Chen (2001) noted that the lack of financial support could impair individuals' ability to become adults and take up their roles as adults successfully. In other words, parental financial helps student to avoid negative financial impacts.

\section{Conceptual Framework}

Research demonstrates that parental involvement is an interactive process between the child and parents that provides a path to student success in their academic performance. Although there are many theories regarding parental support at the college level, in this parental study, involvement is defined in terms of social support, emotional support, and financial support (Figure 1). These variables have been indicated in the literature to lead to better academic college performance of students.

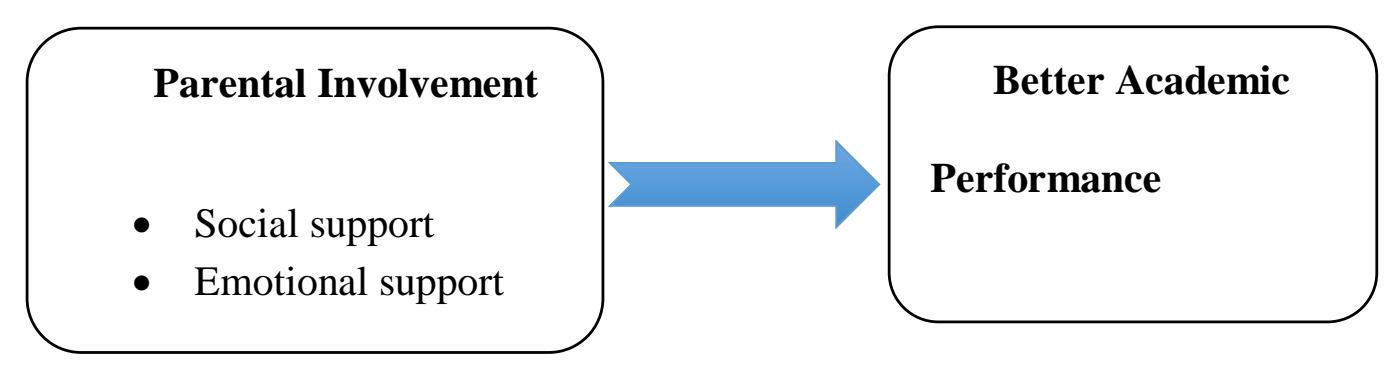

Figure 1. Conceptual Framework for the study

\section{METHODS}

A cross-sectional survey design was used for this quantitative research. Creswell (2003) posited that survey research design could be used in quantitative research to capture the attitude, opinions, or characteristics of the population. This data gathering method from respondents 
enables the researcher to assess attitudes, viewpoints, traits, and practices. Creswell also emphasized that utilizing survey research design allows testing of research hypotheses, and the using participants' responses can be statistically analyzed. Thus, the survey research design was most applicable to this study since it was aimed at capturing the participants' perceptions and attitudes.

\section{Participants and Sampling Method}

Participants of this study were 253 undergraduate students at Asia-Pacific International University (AIU) aged between 17 years old to 25 years old. Stratified sampling was used to select subgroups from 5 dormitories. These subgroups included gender segregation, nationality, department, and age.

\section{Instrument}

The survey consisted of a demographic questionnaire and a Likert-scale survey instrument. The questionnaire included a series of self-report questions in the English language for international students In addition, the questionnaire consisted of two parts. The first part included the demographics (gender, age group, and nationality, number of siblings, departments, and CGPA grades) and the second part consisted of 13 statements about parental involvement Each statement was measured along a 5-point Likert Scale from 1-strongly disagree to 5-strongly agree. The 13 statements were designed to measure four aspects of parental involvement: family relationship, economic support, social support, and emotional support.

Validity and Reliability

The 13-item parental involvement questionnaire was developed by the researcher and was designed to measure four aspects of parental involvement: family relationship, economic support, social support, and emotional support. Family relationship and social support items were generated from the works of Román, Cuestas, and Fenollar (2008). Items for economic support and emotional support were adapted from Cheng, Ickes, and Verhofstadt (2012). An expert in quantitative research, Dr. Octavian Mantiri, was asked to examine the appropriateness and adequacy of the item assessing parental involvement. He judged that the items were indeed reasonable measures of parental involvement. The internal consistency reliability, Cronbach's alpha (Cronbach, 1951) of the 13-item parental involvement survey was .914 for the pilot study and .88 for the final data. Nunnally (1978) considers reliability estimates of .7 as adequate for non-cognitive scales. Thus, the instrument used in this study is internally consistent. 


\section{Pilot Testing}

For pilot testing, the questionnaire was distributed to 20 students sampled through convenience sampling methods. The purpose of pilot testing provided better information for the researcher on whether the questionnaire was suitable and effective in fulfilling the purpose of the study. Care was taken to ensure the participants were selected to represent the various dimensions that are important to the study in terms of age, gender, and academic year.

Procedures

A research assistant administered the questionnaire to 300 students in AIU. Using stratified sampling methods, 60 participants from each dormitory on campus participated. This was done through the assignment of numbers from a name list which had been provided. These respondents had an equal probability of being chosen regardless of their nationality, age, or cross-section of class. The respondents were then put in groups according to gender, age, department and nationality. During data collection, participants were first given a cover page which contained information about the study and sentences that required the participant to read and to provide consent for participating in the study. The respondents were not forced to participate. They were asked to fill in the survey during their free time. Upon completion, the questionnaire was returned to the researcher's assistant. The completed questionnaires were sent by post to the researcher. Upon receipt, each completed questionnaire was coded to avoid duplication. The data were keyed into the computer and then analyzed using Statistical Package for the Social Sciences (SPSS).

Data Analysis

Demographic data from the instrument were analyzed using descriptive statistics and presented using tables. Indicators included the number of participants by gender, age group, marital status, nationality, number of siblings, department, CGPA result, etc. An independent samples t-test was used to determine the differences between Thai and International students on parental support. Spearman rho correlation coefficients between parental involvement variables and cumulative grade point averages (CGPA) were reported. Data analysis was done independently by the researcher using the Statistical Package for Social Sciences (SPSS) for Windows, Version 21. Before analyzing the data, the entire data set was screened for missing data and data entry mistakes. 


\section{RESULTS}

\section{Participants characteristics}

In this study, there were 253 participants comprising 150 females (59.3\%) and 103 males $(40.7 \%)$ in this group. The age of the participants ranged from 15 to 30 years old. Majority of the group aged within $21-23$ years old $(41.5 \%)$.

As shown in Table 1, most of the participants were International students comprising of 182 students (71.9\%) whereas only 71 (28.1\%) were Thai students. Participants were categorized as Thai and international.

Students who had citizenships from other countries were grouped as international students. These participants came from five different majors, which were Arts \& Humanity (28.5\%), Education \& Psychology (18.2\%), Business Administration (27.3\%), Science (8.7\%), Religious Studies (9.5\%), Nursing (5.5\%), and ESL (2.4\%). There were fifty-two (20.6\%) participants have more than five siblings.

Participants were asked to report on their Cumulative Grade Point Average (CGPA) result. About two-thirds (65.6\%) had CGPA between 2.6 and 3.5. Forty-two students (16.6\%) had CGPA of 3.6-4.0. Most of the participants were in their freshman year (40.7\%). There were also participants who were in their sophomore year (24.9\%), senior year (20.9\%), and junior year $(13.4 \%)$. Majority of the participants were staying in the university dormitory $(84.6 \%)$, whereas $15.4 \%$ of the participants were either staying on their own, with their parents or with relatives. There were $154(60.9 \%)$ of the participants' parents are working, and $99(39.1 \%)$ participants reported only one of their parents are working.

\section{Demographic Characteristics}

Table 1. Demographic Characteristics of Participants $(n=253)$

\begin{tabular}{cl|l|l}
\hline Characteristics of group & Frequency & Percentage \\
\hline \multirow{2}{*}{ Gender } & Male & 103 & 40.7 \\
& Female & 150 & 59.3 \\
& Total & 253 & 100.0 \\
\hline \multirow{2}{*}{ Age } & $15-17$ years old & 5 & 2.0 \\
& $18-20$ years old & 87 & 34.4 \\
& $21-23$ years old & 105 & 41.5 \\
& $24-26$ years old & 39 & 15.4 \\
$27-29$ years old & 9 & 3.6 \\
& 30 and above years old & 8 & 3.2 \\
Nationality & Total & 253 & 100.0 \\
& Thai & 71 & 28.1 \\
& International & 253 & 71.9 \\
& Total & 100.0 \\
\hline
\end{tabular}




\begin{tabular}{|c|c|c|c|}
\hline Siblings & $\begin{array}{l}\text { None } \\
1 \\
2 \\
3 \\
4 \\
5 \text { and above } \\
\text { Total }\end{array}$ & $\begin{array}{l}25 \\
54 \\
48 \\
37 \\
37 \\
52 \\
253\end{array}$ & $\begin{array}{l}9.9 \\
21.3 \\
19.0 \\
14.6 \\
14.6 \\
20.6 \\
100.0\end{array}$ \\
\hline Department & $\begin{array}{l}\text { Arts \& Humanity } \\
\text { Education \& Psychology } \\
\text { Business Administration } \\
\text { Science } \\
\text { Religious Studies } \\
\text { Nursing } \\
\text { ESL } \\
\text { Total }\end{array}$ & $\begin{array}{l}72 \\
46 \\
69 \\
22 \\
24 \\
14 \\
6 \\
253\end{array}$ & $\begin{array}{l}28.5 \\
18.2 \\
27.3 \\
8.7 \\
9.5 \\
5.5 \\
2.4 \\
100.0\end{array}$ \\
\hline CGPA & $\begin{array}{l}\text { Below } 2.0 \\
1.1-2.5 \\
2.6-3.0 \\
3.1-3.5 \\
3.6-4.0 \\
\text { Total }\end{array}$ & $\begin{array}{l}6 \\
39 \\
85 \\
81 \\
42 \\
253\end{array}$ & $\begin{array}{l}2.4 \\
15.4 \\
33.6 \\
32.0 \\
16.6 \\
100.0\end{array}$ \\
\hline Academic Year & $\begin{array}{l}\text { Freshman } \\
\text { Sophomore } \\
\text { Junior } \\
\text { Senior } \\
\text { Total }\end{array}$ & $\begin{array}{l}103 \\
63 \\
34 \\
53 \\
253\end{array}$ & $\begin{array}{l}40.7 \\
24.9 \\
13.4 \\
20.9 \\
100.0\end{array}$ \\
\hline Staying with & $\begin{array}{l}\text { By myself } \\
\text { In the university dormitory } \\
\text { My parents } \\
\text { Relatives } \\
\text { Total }\end{array}$ & $\begin{array}{l}15 \\
214 \\
22 \\
2 \\
253\end{array}$ & $\begin{array}{l}5.9 \\
84.6 \\
8.7 \\
.8 \\
100.0\end{array}$ \\
\hline Working parents & $\begin{array}{l}\text { Both parents are working } \\
\text { Only one of the parents Is } \\
\text { working } \\
\text { Total }\end{array}$ & $\begin{array}{l}154 \\
99 \\
253\end{array}$ & $\begin{array}{l}60.9 \\
39.1 \\
100.0\end{array}$ \\
\hline
\end{tabular}

\section{Nature of Parental Involvement}

Descriptive statistics and reliability estimates for measures of parental involvement are reported in Table 2. Internal consistency reliability estimates for family relationship, social support, and emotional support are acceptable (all are greater than .7). The reliability estimates for Q5 (provide financial assistance) and Q6 (must work/pay for my education) as measures of economic support was quite low (.35) and therefore reported separately.

Overall, measures of parental involvement are positive. The participants 'agree' that family relationship is positive $(\mathrm{M}=3.96, \mathrm{SD}=0.72)$, and that there is strong social $(\mathrm{M}=3.88, \mathrm{SD}=0.72)$ and emotional $(\mathrm{M}=4.06, \mathrm{SD}=0.89)$. They also agree $(\mathrm{M}=4.06, \mathrm{SD}=1.09)$ that their parents 
provide financial assistance; thus, only some must work to pay for their education $(\mathrm{M}=2.98$, $\mathrm{SD}=1.29)$.

Table 2. Descriptive Statistics of Parental Involvement $(n=253)$

\begin{tabular}{lc|c|c|c|c}
\hline Cronbach's Variable & M & SD & skewness & \#items & alpha \\
\hline Family relationship & 3.96 & 0.72 & 0.86 & 4 & 0.82 \\
\hline Economic support & & & & & \\
\hline Q5 provide financial assistance & 4.06 & 1.09 & -1.13 & & \\
\hline Q6 Have to work/pay for my own education & 2.98 & 1.29 & 0.11 & & \\
\hline Social support & 3.88 & 0.72 & -0.95 & 5 & 0.78 \\
\hline Emotional support & 4.06 & 0.89 & -1.10 & 2 & 0.79 \\
\hline
\end{tabular}

Table 3. Family relationship descriptive statistics

\begin{tabular}{ll|l|l|l}
\hline & \multicolumn{1}{c|}{ N } & M & SD & $\%$ \\
\hline Close relationship with family & 253 & 4.26 & 0.82 & 84.2 \\
\hline Often contact family & 253 & 3.88 & 0.90 & 66.8 \\
\hline Family is my role model & 253 & 3.87 & 0.95 & 70.4 \\
\hline Communicate openly with family & 253 & 3.84 & 0.93 & 70.3 \\
\hline
\end{tabular}

aPercent 'agree' and 'strongly agree.'

Table 3 describes the opinion of students about the family relationship. The participants appear to have a close relationship with their family $(\mathrm{M}=4.26, \mathrm{SD}=0.83)$; are often in contact with them $(\mathrm{M}=3.88, \mathrm{SD}=0.90)$; agree that their family is their role model $(\mathrm{M}=3.87, \mathrm{SD}=0.95)$; and communicate openly with their family $(\mathrm{M}=3.84, \mathrm{SD}=0.93)$. Percentage of participants who 'agree' or 'strongly agree' to the questions describing family relationship range from $67 \%$ (often contact family) to $84 \%$ (close relationship with family).

Table 4. Economic support descriptive statistics

\begin{tabular}{ll|l|l|l}
\hline & $\mathrm{N}$ & $\mathrm{M}$ & $\mathrm{SD}$ & $\%$ \\
\hline Family provide financial assistance & 253 & 4.06 & 1.09 & 74.7 \\
\hline I must work/pay for my education & 253 & 2.98 & 1.29 & 34.0 \\
\hline
\end{tabular}

Table 4 describes the opinion of students about their financial assistance. The participants appear to receive financial assistance from their family $(\mathrm{M}=4.06, \mathrm{SD}=0.83)$ and must work to pay for their education $(\mathrm{M}=2.98, \mathrm{SD}=1.26)$. 
Table 5. Social support descriptive statistics

\begin{tabular}{ll|l|l|r}
\hline & $\mathrm{N}$ & $\mathrm{M}$ & $\mathrm{SD}$ & $\%$ \\
\hline Family proud when I get good grades & 253 & 4.38 & 0.81 & 86.5 \\
\hline Family encouraged me to get good grades & 253 & 4.17 & 0.85 & 78.7 \\
\hline Family support extra-curricular activities & 253 & 3.72 & 0.96 & 65.3 \\
\hline I report/discuss academic results & 253 & 3.71 & 1.08 & 63.2 \\
\hline Family and I discussed what programs I take & 253 & 3.40 & 1.20 & 54.6 \\
\hline
\end{tabular}

Table 5 describes the opinion of students about their social support. The participants appear that their family are proud when they get good grades $(\mathrm{M}=4.38, \mathrm{SD}=0.81)$; family encourage them to get good grades $(\mathrm{M}=4.17, \mathrm{SD}=0.85)$; family support extra-curricular activities $(\mathrm{M}=3.72, \mathrm{SD}=0.96)$; students report or discuss their academic results with their family $(\mathrm{M}=3.71, \mathrm{SD}=1.08)$; and students discuss with their family on what programs to take $(\mathrm{M}=3.40$, $\mathrm{SD}=1.20)$.

Table 6. Emotional support descriptive statistics

\begin{tabular}{ll|l|l|l}
\hline & $\mathrm{N}$ & $\mathrm{M}$ & $\mathrm{SD}$ & $\%$ \\
\hline Family concern with my well being & 253 & 4.11 & 0.94 & 78.2 \\
\hline Family give guidance when needed & 253 & 4.01 & 1.03 & 74.3 \\
\hline
\end{tabular}

Table 6 describes the opinion of students about their emotional support. The participants appear that their family concerned with their well-being $(\mathrm{M}=4.11, \mathrm{SD}=0.94)$ and their family provide them guidance $(\mathrm{M}=4.01, \mathrm{SD}=1.03)$.

\section{Academic performance}

Table 7. Distribution of cumulative grade point averages

\begin{tabular}{|l|l|l|}
\hline CGPA & $\mathrm{n}$ & $\%$ \\
\hline $0.0 \leq 2.0$ & 6 & 2.4 \\
\hline $2.1-2.5$ & 39 & 15.4 \\
\hline $2.6-3.0$ & 85 & 33.6 \\
\hline $3.1-3.5$ & 81 & 32.0 \\
\hline $3.6-4.0$ & 42 & 16.6 \\
\hline
\end{tabular}


Table 7 shows the distribution of cumulative grade point averages of the students in this study. Result shows $33.6 \%(n=85)$ of the respondent's CGPA were within 2.6 to 3.0 , followed by $32 \%(n=81)$ with CGPA between 3.1 and 3.5. Thirty-two percent $(n=42)$ reported CGPA between 3.6 and 4.0. About $18 \%(n=45)$ had CGPA of 2.5 or lower.

\section{Differences in parental support between Thai and International Students}

Independent samples t-test results for comparing Thai and International students on five measures of parental support are reported in Table 8. Effect sizes are also reported. The analysis showed no significant differences for the family providing financial assistance, social support, and emotional support. Thai students reported significantly higher levels of family relationship ( $\mathrm{M}=4.15, \mathrm{SD}=0.56)$ than international students $(\mathrm{M}=3.89, \mathrm{SD}=0.77)$. However, they are significantly more likely to have to work/pay for their education $(\mathrm{M}=3.55, \mathrm{SD}=1.24)$ than International students $(\mathrm{M}=2.75, \mathrm{SD}=1.24)$. The magnitude of the differences between these two areas between Thai and International students are medium (ES=.43 and 0.64). Overall, it appears Thai students receive higher parental support than international students.

Table 8. Independent samples t-test results comparing Thai and International students.

\begin{tabular}{l|ll|l|l|l|l|l|l}
\hline Variable & Nationality & $\mathrm{N}$ & $\mathrm{M}$ & $\mathrm{SD}$ & $\mathrm{t}$ & $\mathrm{df}$ & $\mathrm{p}$ & $\mathrm{ES}(\mathrm{d})$ \\
\hline $\begin{array}{l}\text { Family } \\
\text { Relationship }\end{array}$ & Thai & 71 & 4.15 & 0.56 & 3.065 & 174.62 & .003 & 0.43 \\
\cline { 2 - 10 } & International & 182 & 3.89 & 0.77 & & & & \\
\hline $\begin{array}{l}\text { Provide } \\
\text { financial } \\
\text { assistance }\end{array}$ & Thai & 71 & 4.24 & 0.87 & 1.824 & 169.17 & .070 & 0.26 \\
\cline { 2 - 11 } & International & 182 & 4.00 & 1.16 & & & & \\
\hline $\begin{array}{l}\text { Work/pay for } \\
\text { own } \\
\text { education }\end{array}$ & Thai & 71 & 3.55 & 1.24 & 4.594 & 251.00 & $<.00$ & 0.64 \\
\hline $\begin{array}{l}\text { Social } \\
\text { Support }\end{array}$ & International & 182 & 2.75 & 1.24 & & & & \\
\hline $\begin{array}{l}\text { Emotional } \\
\text { Support }\end{array}$ & Thai & 71 & 3.96 & 0.53 & 1.437 & 186.21 & .152 & 0.20 \\
\hline
\end{tabular}

\section{Parental Support and Academic Performance}

Spearman rho correlation coefficients between parental involvement variables and cumulative grade point averages (CGPA) are reported in Table 9. Correlation among parental involvement variables range from negligible $(r=-.06, p>.05)$ between family providing financial assistance 
and having to work/pay for education to large $(\mathrm{r}=.71, \mathrm{p} \leq .01)$ between social support and emotional support. Correlation between CGPA and family relationship variables are negligibly ranging from .01 to -.15 . Correlation between family relationship and CGPA $(r=-.15)$ is negative and negligible, though statistically significant $(\mathrm{p} \leq .05)$. Only about $2 \%\left(\mathrm{r}^{2}=.0225\right)$ of the variance in CGPA can be explained by family relationship. The correlation between 'work/pay for my education' and CGPA ( $\mathrm{r}=-.13)$ is also negative and negligible, though statistically significant $(\mathrm{p} \leq .05)$. Less than $2 \%\left(\mathrm{r}^{2}=.0169\right)$ of the variance in CGPA can be explained by 'work/pay for my education.' CGPA is not related to family providing financial assistance, social and emotional support. These results suggest that CGPA cannot be adequately explained by parental involvement.

Table 9. Relationship between parental support and academic performance $(n=253)$

\begin{tabular}{l|l|l|l|l|l}
\hline & \multicolumn{2}{l}{ Spearman rho } & \multicolumn{2}{l}{} \\
Variables & 2 & 3 & 4 & 5 & 6 \\
\hline Family relationship & $.29^{* *}$ & $.22^{* *}$ & $.54^{* *}$ & $.54^{* *}$ & $-.15^{*}$ \\
\hline Family provide financial assistance & & -.06 & $.42^{* *}$ & $.36^{* *}$ & .02 \\
\hline I must work/pay for my education & & $.19^{* *}$ & .10 & $-.13^{*}$ & \\
\hline Social support & & & & $.71^{* *}$ & .02 \\
\hline Emotional support & & & & .01 \\
\hline Academic performance (CGPA) & & & & \\
\hline${ }^{*} \mathrm{p} \leq .05,{ }^{* *} \mathrm{p} \leq .01$ & & & & \\
\hline
\end{tabular}

Tables 10 and 11 are cross-tabulations between family relationship and CGPA, and between work/pay for education and CGPA respectively. In Table 10, the percentage of participants who reported high CGPA (3.1-4.0) is $61.6 \%$ for those with a negative family relationship, 59\% for those with the neutral relationship, and $44.6 \%$ for those with positive relationships. This result explains why there is a negative correlation $(\mathrm{r}=-.15)$ between family relationship and CGPA, as reported in Table 9. However, in this analysis, the Chi-square result indicates that the relationship between family relationship and CGPA is not statistically significant $\left(\chi^{2}=6.94\right.$, $\mathrm{df}=8, \mathrm{p}=.54)$. 
Table 10. Family relationship and CGPA

\begin{tabular}{c|c|c|c|c|c}
\hline $\begin{array}{l}\text { CGPA } \\
\text { Family }\end{array}$ & $0.0 \leq 2.0$ & $2.1-2.5$ & $2.6-3.0$ & $3.1-3.5$ & $3.6-4.0$ \\
Relationship & & & & & \\
\hline Negative & & $1(7.7)$ & $4(30.8)$ & $4(30.8)$ & $4(30.8)$ \\
\hline Neutral & $1(1.8)$ & $7(12.5)$ & $15(26.8$ & $24(42.9)$ & $9(16.1)$ \\
\hline Positive & $5(2.7)$ & $31(16.8)$ & $66(35.9)$ & $53(28.8)$ & $29(15.8)$ \\
\hline
\end{tabular}

$\chi^{2}=6.94, \mathrm{df}=8, \mathrm{p}=.54$ Cramer's $\mathrm{V}=.12$

In Table 11, the percentage of participants who reported high CGPA (3.1-4.0) is $53.1 \%$ for those who disagreed that they work/pay for their education and $44.2 \%$ for those who agreed that they work/pay for their education. About $48 \%$ of those who were not sure had high CGPA. This result explains the negative correlation between work/pay for education and CGPA, as reported in Table 11. However, in this analysis, the Chi-square result indicates that work/pay for education and CGPA is not statistically significant $\left(\chi^{2}=8.17, \mathrm{df}=8, \mathrm{p}=.42\right)$.

Table 11. Work/pay for education and CGPA

\begin{tabular}{lc|c|c|c|c}
\hline & CGPA & & & \\
Work/Pay Education & $0.0 \leq 2.0$ & $2.1-2.5$ & $2.6-3.0$ & $3.1-3.5$ & $3.6-4.0$ \\
\hline Negative (1-2.5) & $2(2.0)$ & $12(1.2)$ & $32(32.7)$ & $28(28.6)$ & $24(24.5)$ \\
\hline Neutral (2.6-3.5) & $2(2.9)$ & $11(15.9)$ & $23(33.3)$ & $25(36.2)$ & $8(11.6)$ \\
\hline Positive (3.51-4.0) & $2(2.3)$ & $16(18.6)$ & $30(34.9)$ & $28(32.6)$ & $10(11.6)$ \\
\hline
\end{tabular}

$\chi^{2}=8.17, \mathrm{df}=8, \mathrm{p}=.42$ Cramer's $\mathrm{V}=.13$

\section{DISCUSSION}

\section{Nature of Parental support}

Parental support, in this study, consisted of having social relationships with their college children. This means that the child received economic, social, and emotional support comfortably. The findings in this study indicated that the internal consistency reliability estimates for family relationship, social support, and emotional support are acceptable. Overall, measures of parental supports are positive where the participants agree that family relationship is positive, and there is strong social and emotional support. The participants also agreed that their parents provided financial assistance. However, there are some who worked to pay for their education. Percentage of participants who 'agreed' or 'strongly agreed' to the questions 
describing family relationship range from $67 \%$ (often contact family) to $84 \%$ (close relationship with family).

In recent years parents have been more involved in the education of their college students. Barker \& Roberts (2015) attribute this parent involvement with this age group to excessive college tuition. Many college students do not have adequate funding to support themselves in college. This finding supports previous literature that points out the consequences of rising educational costs (Jack, 2003; Johnstone, 2005; Savage, 2009) Adjusting to college life has been marked as an important step in the psychosocial development of individuals. As students attempt to develop a consistent identity, they depend largely on psychological set-up developed under the influence of parents (Leonard, 2013). It could be said that this phase of life, although integrated with parental support, has little effect on the student academic performance. As the student matures, he or she develops an certain level of maturity, which could include financial and emotional stability. Parental support is shown to be significant during childhood when the child has not developed emotional and mental security (El Nokali, Bachman, \& Votruba-Drzal, 2001).

\section{Differences in Parental Support Between Thai and International Students}

Independent samples t-test results revealed that there are no significant differences for the family providing financial assistance, social support, and emotional support. The data shows that Thai students reported significantly higher levels of family relationship $(\mathrm{M}=4.15$, $\mathrm{SD}=0.56)$ than international students $(\mathrm{M}=3.89, \mathrm{SD}=0.77)$. Moreover, they are significantly more likely to have to work/pay for their education $(\mathrm{M}=3.55, \mathrm{SD}=1.24)$ than International students $(\mathrm{M}=2.75, \mathrm{SD}=1.24)$. The magnitude of the differences between these two areas between Thai and International students are medium (ES=.43 and 0.64). Based on these findings, parental support for Thai students could be determined to be of a higher level compared to International students. This can be explained by the fact that Thai students live closer to their parents and have easier access to them for support when they need it.

In addition, the Thai culture promotes the respect of adults and therefore Thai student defer critical issues and decisions to their parents. Parents also regard their college-age students as children and push them to take on careers the parents think fit their children. Therefore, it is obvious that they would get involved in their children's decisions.

\section{Parental Support and Academic Performance}

The findings revealed that academic performance could not be adequately explained by parental support. Correlation among parental support variables ranges from negligible between 
family providing financial assistance and having to work and pay for their education to large between social support and emotional support ( $r=-.06, \mathrm{p}>.05)$. These can be explained where the correlation between family relationship and CGPA $(\mathrm{r}=-.15)$ is negative and negligible. Correlation between "work and pay for my education" and CGPA is also negative and negligible. Therefore, CGPA is not related to family providing financial assistance, social or emotional support. Participants in this study reported high parental support related to the family relationship, social support, and emotional support. Approximately half of the participants reported a CGPA of 3.1 to 4.0. About a third of the participants reported CGPA of 2.6 to 3.0. Thai students reported significantly higher levels of parental relationship and are more likely to have to work/pay for their education. Therefore, we can conclude that parental support cannot adequately explain academic performance among students in this study.

The research reveals that although parental support has a negligible influence on academic performance, there is still a positive influence on the family relationship between the parents and students in higher education level. According to literature reviews on the effects of parental support, literature state that parental support does impact the academic outcome and career prospects of the child in the future (Heffer, 2009). Some studies do show that there is an indirect correlation between parental involvement and academic performance, in that students who have financial and emotional support do better because they have the needed support. Harper, Sax \& Wolf, 2012 indicate that emotional support provides stability. In addition, Kek, Darmawan, and Chen (2007) argue students who have supportive parents are secure and have self-efficacy, which helps them to concentrate on their studies.

It is likely that these results, from the cross-sectional survey, were unable to depict the varying levels of parental support throughout the livelihood of the student. This explains the differing conclusions which deemed parental support as necessary for the students' academic excellence, during childhood rather than during college (El Nokali, Bachman, \& Votruba-Drzal, 2010). Students are also more independent in college, which may explain these study findings. However, students also desire to get psychological, financial assistance from their parents and consider parental support crucial for academic growth. Turner, Chandler, \& Heffer (2009) illustrated that when barriers limit parents from becoming involved, the consequences might affect students' academic performance. 


\section{DISCUSSION}

\section{Conclusion}

The research reveals that although the family relationship between parents and children has a positive influence on college education, it does not adequately explain academic performance among students in this study. Both the multifaceted nature of parental support and different measurements of academic achievement have probably contributed to the inconsistencies. The students' perspective in this study is that students strongly favored the importance of parents' support at the university level. Majority of students had good communication with their parents about their university activities and well-being.

\section{Recommendation}

The findings show the importance of parental involvement and as such, it is recommended that parents build up a relationship of trust with their children from the beginning of their early childhood days to ensure that their children adopt better learning attitudes and processes. Although parents can provide emotional support, these forms of support may not translate into the end goal of academic success for their children. Instead, parents can invest in the institutions of higher learning that will promote the improvement of the students' academic achievement as an alternative form of ensuring the academic success of their college children.

The findings would help educators and parents to familiarize themselves with the best parental involvement approaches for college students. The Institutions should also consider developing policies and programs that educate parents in ways they can get involved in their children's education, even if they do not have a high level of education.

Future research should consider using mixed method research design including interviews for data collection in order to get in-depth understanding of parental support at the college level. 


\section{REFERENCES}

Arnett, J. J. (2000), Emerging adulthood: A theory of the development of the late teens through the twenties. American Psychologist, 55(5):469-480.

Arshad, M., Shahzadi, E., \& Mahmood. A. (2016). Parents' involvement at the university level education: Students' perception in under developing country. European Scientific Journal, 12(22), 294-304.

Astin, A. W. (1968). The college environment. Washington, DC: American Council on education.

Barker, O., \& Roberts, D. D. (2015). Parental involvement as a moderator to the relationship between exposure to violence and academic outcomes among youth of African descent. Journal of Negro Education, 84(3), 416-427.

Borders, L. D., Hines, E. M., Gonzalex, L. M., Villalba, J. A., \& Hendersen, A. (2011). Parental involvement in college planning: a report for the College Foundation of North Carolina. Working Paper. Retrieved fromhttp://www.researchgate.net/publication/313113148_Parental_involvement_in_c ollege_planning_A_report_for_the_College_Foundation_of_North_Carolina

Brunello, G., \& De Paola, M. (2010). Peer effects in higher education: Does the field of study matter? Economic Inquiry, 48(3), 621-634.

Ceja, M. (2004). Chicana college aspirations and the role of parents: Developing educational resiliency. Journal of Hispanic Higher Education, 61(1), 111-130. https://doi.org/10.1177/1538192704268428

Cheng, W., Ickes, W., \& Verhofstadt, L. (2012). How is family support related to students' GPA Scores? A longitudinal study. Higher Education, (64(3), 399-420.

Doi:10.1007/s10734-011-9501-4

Chickering, A. W., \& Reisser, L. (1993). Education and identity (2nd ed.). San Francisco: Jossey-Bass.

Coleman, J. (1988). Social capital in the creation of human capital. The American Journal of Sociology, 94, S95-S120.

Creswell, J. W. (2003). Research design: Qualitative, quantitative, and mixed methods approaches (2nd ed.). Thousand Oaks, CA: Sage.

Cronbach, L. J. (1951). Coefficient alpha and the internal structure of tests. Psychometrika, 16(3), 297-334.

Edelman, E. (2013). The effects of parental involvement on the college student transition: A qualitative study at a large Midwestern University. (Unpublished Master of Arts thesis). University of Nebraska. Lincoln, Nebraska. 
Fan, X., \& Chen, M. (2001). Parental involvement and students' academic achievement: A meta-analysis. Educational Psychology Review, 13(1), 1-22.

Flowers III, A. M. (2015). The Family Factor: The Establishment of Positive Academic Identity for Black Males Engineering Majors. Journal of Black Studies, 39(1), 64-74.

Harper, C. E., Sax, L. J. \& Wolf D. S. (2012). The role of parents in college students' sociopolitical awareness, academic, and social development. Journal of Student Affairs Research and Practice 49(2). 137-156. https://doi.org/10.1515/jsarp-2012-6147

Jack, L. (2003). Maximizing College Readiness for all through parental support. School Community Journal, 23(1), 183-202.

Jeynes, W. H. (2007). The relationship between parental involvement and urban secondary school student academic achievement: A meta-analysis. Urban Education, 42(1), 82110.

Johnstone, D. B. (2005). Financing higher education: Who should pay? In P. G. Altbach, R. O. Berdahl, \& P. J. Gumport (Eds.), American higher education in the twenty-first century (2nded., pp. 369-392). Baltimore: The Johns Hopkins University Press.

Kek, M. A. Y., Darmawan, I. G. N., \& Chen, Y. S. (2007). Family, learning environments, learning approaches, and student outcomes in a Malaysian private university. International Education Journal, 8(2), 318-336.

Kiyama, J. M., \& Harper, C. E. (2015).The relationship between college students and their families. Family Engagement in Higher Education, 41(6), 1-94. https://doi.org/10.1002/aehe.20024

Kwon, K. A., Yoo, G. \& Bingham, G.E. (2016). Helicopter parenting in emerging adulthood: Support or barrier for Korean college students' psychological adjustment. Journal of Child and Family Studies, 25(1) 136-145. https://doi.org/10.1007/s10826-015-0195-6

LeMoyne, T. \& Buchanan, T. (2011) Does "hovering" matter? Helicopter parenting and its effect on well-being, Sociological Spectrum, 31(4) 399-418. Doi.1080/02732173.2011.574038

Leonard, J. (2013). Maximizing college readiness for all through parental support. School Community Journal, 23(1), 183-202.

Littleton, R. A. (2002). Campus involvement among African American students at a small predominantly white colleges. College Student Affairs Journal 21(2), 53-67.

Ma, Y. (2009). Family socioeconomic status, parental involvement and college major choices: Gender, race/ethnic and nativity patterns. Sociological Perspectives 52(2), 211-234. https://doi.org/10.1525/sop.2009.52.2.211 
Nunnally, J. C. (1978). Psychometric theory (2 ${ }^{\text {nd }}$ ed.). New York: McGraw-Hill.

Perna, L. W., \& Thomas, S. L. (2008). Theoretical perspectives on student success: Understanding the contributions of the disciplines. ASHE Higher Education Report Series. San Francisco: Jossey-Bass.

Rabia, M., Mubarak, N. Tallat, H. \& Nasir, W. (2017). A study on study habits and academic performance of students. International Journal of Asian Social Science, 7(10), 891897.

Ratelle, C.F., Larose, S., Guay, F., \& Sene'cal, C. (2005). Perception of parental involvement and support as predictors of college students' persistence in Science curriculum. Journal of Family Psychology, 19 (2), 286-293. Doi: 10.1037/0893-3200.19.2.286

Román, S., Cuestas, P. J., \& Fenollar, P. (2008). An examination of the interrelationships between self-esteem, others' expectations, family support, learning approaches, and academic achievement. Studies in Higher Education, 33(2), 127-138.

Savage, M. (2009). The case for parental involvement during the college years. A paper presented at the National Conference of Law and Higher Education (February 21, 2009) Orlando, FL.

Sax, L. J. \& Weintraub, D. S. (2014). The parental role in first-year students' emotional well-being: considerations by gender, Journal of Student Affairs Research and Practice, 51(2), 113-127, Doi: 10.1515/jsarp-2014-0013

Schiffrin, H. H., Liss, M., Miles-McLean, H., Greary, K. A., Erchull, M. J., \& Tashner, T. (2014). Helping or hovering: The effects of helicopter parenting on college students' well-being. Journal of Child and Family Studies, 23(3), 548-557.

Schoeni, R., \& Ross, K. (2004). Family support during the transition to adulthood [Policy brief]. Network on Transition to Adulthood, 12, 1-2.

Scoppa, V., \& De Paola, M. (2010). Peer group effects on the academic performance of Italian students. Applied Economics 42(17), 2203-2215. Doi: 10.1080/00036840701765478

Shaw, T. A. (2005). College bound: What Christian parents need to know about helping their kids choose a college. Chicago, IL: Moody Publishers.

Shahzadi, E., \& Ahmad, Z. (2011). A study on academic performance of university students. A paper presented at the $8^{\text {th }}$ International Conference on Recent Advances in Statistics, February 8-9, 2011, 255-268, Labore, India. Retrieved from https://www.researchgate.net/publication/266736633_A_STUDY_ON_ACADEMIC_ PERFORMANCE_OF_UNIVERSITY_STUDENTS

Smith, M. J., \& Fleming, M. K. (2006). African-American parents in the search stage of college choice: Unintentional contributions to the female to male college enrollment gap. Urban Education, 41(1), 71-100. https://doi.org/10.1177/0042085905282255 
Spain, B. (2008). Family diversity: A quantitative study of the impact of divorce and family structure on the academic performance of college students. Dissertation Abstracts International Section A: Humanities and Social Sciences, 68(12-A), 4981.

Suizzo, M.-A., \& Soon, K. (2006). Parental Academic Socialization: Effects of home-based parental involvement on locus of control across U.S. ethnic groups. Educational Psychology, 26(6), 827-846.

Tinto, V. (1993). Leaving college: Rethinking the causes and cures of student attrition. Chicago, University of Chicago Press.

Tugend, A. (2014). Beyond a parents' reach: When a child legally becomes an adult. New York Times. Retrieved from https://www.nytimes.com/2014/11/01/your-money/whena-child-legally-becomes-an-adult.html

Turner, E. A., Chandler, M. \&Heffer, R. W. (2009). The influence of parenting styles, achievement motivation, and self-efficacy on academic performance in college students. Journal of College Student Development, 50(3), 337-346.

Wayne, A., Garet, M., Wellington, A., \& Chiang, H. (2018). Promoting educator effectiveness: The effects of two key strategies. NCEE 2018-4009. Retrieved from https://eric.ed.gov/contentdelivery/servlet/ERICServlet?accno=ED581618

Weidman, J., DeAngelo, L., \& Bethea, K. (2014). The Weidman Model of undergraduate socialization: Continuity and change- Paper presented at the 2014 Annual Meeting of the American Educational Research Association (AERA), 7 April 2014, Philadelphia, PA

Wentzel, K. R., \& Caldwell, K. (2006). Friendships, Peer Acceptance, and Group Membership: Relations to Academic Achievement in Middle School. Child Development, 68(6), 1198-1209. https://doi.org/10.1111/j.14678624.1997.tb01994.x

Wintre, M. G., Dilouya, B., Pancer, S. M., Pratt, M. W., Birnie-Lefcovitch, S., Polivy, J., \& Adams, G. (2011). Academic achievement in first-year university: Who maintains their high school average?.The International Journal of Higher Education And Educational Planning, 62(4), 467-481.

Winegard, T. A. (2010). Interactions of senior-level student affairs: Administrators with parents of traditional-age undergraduate students. (unpublished dissertation, University of Nebraska, USA). 